\title{
HUBUNGAN ANTARA KADAR LAJU ENDAP DARAH (LED) DENGAN KADAR C-Reaktiv Protein (CRP) PADA PENDERITA TUBERKULOSIS (TBC) DI WILAYAH KERJA PUSKESMAS ALAS BARAT
}

\author{
Nurmawan $^{1}$, Aini ${ }^{1}$, Jumari Ustiawaty ${ }^{1}$ \\ ${ }^{1}$ Program Studi Teknologi Laboratorium Medik, Politeknik Medica Farma Husada Mataram
}

\begin{tabular}{l}
\hline Article Info \\
\hline Article history: \\
Received Dec $25^{\text {th }}, 2019$ \\
Revised Feb $17^{\text {th }}, 2020$ \\
Accepted Feb $19^{\text {th }}, 2020$ \\
\hline
\end{tabular}

\section{Keyword:}

ESR

CRP

Tuberculosis (TBC)

\begin{abstract}
Tuberculosis is a disease caused by rod-shaped bacteria (basil) with another name Mycrobacterium tuberculosis. Mycrobacterium tuberculosis enters the body then causes inflammation, inflammation and bacterial invasion which then induces liver cells to synthesize acute phase C-reactive protein protein (CRP). CRP will increase sharply after inflammation, as well as the formation of aggregates derived from the acute phase protein hormone which causes an increase in the Erythrocyte sedimentation rate (ESR)). The purpose of this study was to determine the relationship Erytrocyte sedimentation rate (ESR) and levels of C-Reactiv protein (CRP) in tuberculosis (TBC) patients. This research is an analytical descriptive study using cross sectional. Data collectors are done using the Non Random Accidental Sampling technique. The number of respondents in this study were 11 people with tuberculosis. Based on the results of this study it is known that TBC patients with smear negative as much as 7 people (63.6\%) and TB patients with positive smear as much as 4 people (36.4\%), both in TB patients with negative smear and positive smear both have levels of ESR not normal with an average ESR level in positive smear of $101.3 \mathrm{~mm} /$ hour and the average ESR level in smear negative is $20.8 \mathrm{~mm} /$ hour. All TBC patients with smear positive CRP levels (not normal) with an average mean value of CRP of $36 \mathrm{mg}$ $/ L$ or an average CRP level in TBC smear negative patients of $0.9 \mathrm{mg}$ / L. Based on the Pearson test results between levels of erythrocyte sedimentation rate (ESR) with C-Reactive protein (CRP) in tuberculosis (TBC) patients obtained a value of $p<0.01(0.000<0.01)$. This shows a strong relationship between LED and CRP levels in TB patients
\end{abstract}

\footnotetext{
ABSTRAK

Tuberkulosis adalah penyakit yang disebabkan oleh bakteri berbentuk batang (basil) dengan nama lain Mycrobacterium tuberculosis. Mycrobacterium tuberculosis memasuki tubuh kemudian menyebabkan peradangan, peradangan dan invasi bakteri yang kemudian menginduksi sel-sel hati untuk mensintesis protein protein fase-C reaktif fase akut (CRP). CRP akan meningkat tajam setelah peradangan, serta pembentukan agregat yang berasal dari hormon protein fase akut yang menyebabkan peningkatan tingkat sedimentasi eritrosit (ESR)). Tujuan dari penelitian ini adalah untuk mengetahui hubungan laju sedimentasi eritrosit (ESR) dan kadar protein C-Reactiv (CRP) pada pasien tuberkulosis (TBC). Penelitian ini merupakan penelitian deskriptif analitik dengan menggunakan cross sectional. Pengumpul data dilakukan dengan menggunakan teknik Non Random Accidental Sampling. Jumlah responden dalam penelitian ini adalah 11 orang dengan
} 
TBC. Berdasarkan hasil penelitian ini diketahui bahwa pasien TBC dengan BTA negatif sebanyak 7 orang $(63,6 \%)$ dan pasien TB dengan BTA positif sebanyak 4 orang $(36,4 \%)$, baik pada pasien TB dengan BTA negatif dan positif. BTA keduanya memiliki kadar ESR yang tidak normal dengan tingkat ESR rata-rata dalam BTA positif 101,3 mm / jam dan tingkat ESR rata-rata dalam BTA negatif adalah 20,8 mm / jam. Semua pasien TBC dengan kadar CRP positif BTA (tidak normal) dengan nilai rata-rata CRP $36 \mathrm{mg} / \mathrm{L}$ atau tingkat CRP rata-rata pada pasien TBC BTA negatif sebesar 0,9 mg / L. Berdasarkan hasil uji Pearson antara kadar eritrosit laju sedimentasi (ESR) dengan protein C-Reactive (CRP) pada pasien tuberkulosis (TBC) memperoleh nilai $\mathrm{p}<0,01(0,000<0,01)$. Ini menunjukkan hubungan yang kuat antara tingkat LED dan CRP pada pasien TB

Kata Kunci : LED, CRP, Tuberkulosis (TBC)

\section{Pendahuluan}

Tuberkulosis (TBC) adalah suatu penyakti infeksi kronik yang menyerang paru-paru. Penyakit Tuberkulosis ini merupakan salah satu masalah kesehatan dunia yang sulit dikendalikan. Secara epidemiologis WHO melaporkan 10-20 juta penderita di dunia mempunyai kemampuan menularkan penyakit Tuberkulosis (TB)(Alsagaff, 2009). Pada tahun 2009 Asia merupakan wilayah dengan jumlah kasus baru sekitar 539.000 dan jumlah kematian sekitar 101.000 jiwa pertahun. Pada tahun 2014, angka penemuankasus TB paru Case Detection Rate (CDR) tercatat sebesar 69,7\%, sedangkan angka keberhasilan pengobatan (success rate - SR) sebesar 90\% (Kementerian Kesehatan Republik Indonesia, 2011)(DepkesRI, 2014). Provinsi NTB mencapai 6.165 pasien TB (semua tipe) dan sebanyak 4.247 orang diantaranya merupakan kasus baru BTA+ (Depkes RI, 2005)

Tuberkulosis disebabkan oleh bakteri Mycobacterium Tuberculosis dan bila masuk kedalam tubuh menyebabkan terjadinya inflamasi. Inflamasi merupakan mekanisme tubuh yang penting untuk mempertahankan diri dari benda asing yang masuk. Pada proses ini sel melepaskan berbagai sitokin proinflamasi, antara lain IL-6 (Interleukulen - 6), selanjutnya IL-6 menginduksi sel hati untuk mensintesis protein fase aktif seperti CRP (C-reaktiv protein) dan fibrinogen yang berfungsi sebagai ofsonin non septic pada proses pagositosis bakteri. Pengukuran sitokin dan protein fase akut dapat digunakan untuk mendeteksi inflamasi (Warnasih, Yulia, Yohan, Artika, \& Sasmono, 2014)

Telah dikenal beberapa pemeriksan pemantauan pengobatan Tuberkulosis seperti LED (Laju endap darah) dengan CRP (C- reaktiv protein). Nilai LED dapat meningkat pada berbagai keadaan infeksi atau inflamasi lain, sehingga LED tidak spesifik untuk TB (Mehta, 2008) .Namun demikian LED bermanfaat sebagai indikator tingkat kestabilan keadaan keseimbangan biologi penderita dan untuk pemantauan keberhasilan pengobatan bila sebelum terapi nilainya tinggi pada pasien Tuberkulosis. Seperti halnya uji LED, CRP merupakan uji non spesifik namun memiliki sensitivitas yang tinggi dengan keberadaannya mendahului peningkatan LED selama inflamasi (Adriana Patricia Muñoz Zapata, 2011)

Tata laksana secara umum untuk Tuberkulosis adalah terapi dengan penggunaan obat anti Tuberkulosis yang terdiri dari beberapa kombinasi diantaranya yaitu Isoniazid, Rifampisin, Pirazinamid, Streptomisin, dan Etambuutol. Tujuan pengobatan adalah untuk memusnakan basil Tuberkulosis dengan cepat dan mencegah kekambuhan 5\%. (Depkes RI, 2005) Berdasarkan penjelasan diatas peneliti tertarik untuk 
melakukan penelitian lebih lanjut mengenai hubungan antara kadar laju endap darah (LED) dengan kadar $C$ Reaktiv protein (CRP) pada penderita Tuberkulosis (TBC) di wilayah kerja Puskesmas Alas Barat.

\section{Metode Penelitian}

Populasi dalam penelitian ini adalah seluruh sampel Penderita yang dinyatakan positif berdasarkan data rekam medik pada periode waktu Desember sampai April sebanyak 25 orang. Sampel dalam penelitian ini adalah pasien TB yang rutin mengkonsumsi obat anti tuberculosis dan mempunyai data awal hasil pemeriksaan LED pada saat awal didiagnosis TB sebanyak 11 orang. Penelitian ini dilakukan di Laboratorium Klinik Puskesmas Alas Barat Kabupaten Sumbawa, NTB dari tanggal 2 Mei - 2 Juni 2018. Merupakan penelitian Deskriptif Analitik dengan pendekatan cross sectional. Pengumpul data dilakukan dengan menggunakan teknik Non Random Acidental Sampling artinya semua pasien dengan pemeriksaan LED dan CRP yang terdata di Laboratorium Klinik Puskesmas Alas Barat. Penanganan sampel dilakuakan berdasarkan data penderita TB yang datang untuk mengambil obat secara berkala ke puskesms kemudian dilakukan pengambilan sampel dahak dan darah untuk pemeriksaan LED dan kadar CRP.

Alat yang digunakan dalam penelitian: a) Pot wadah sputum, b) Objek glass, c) Rak cat, d) Spuit, e) Tissue, f) Tabung LED, g) Rak LED, h) Plastic 1) pengaduk, j) Centrifuge, k) Stopwacth, 1) Mikroskop, m) Slide tes dasar hitam, n) Yellow tip, o) Mikropipet, p) Pipet tetes, q) Batang Pengaduk, r) Tabung reaksi, s) Rak tabung reaksi. Bahan yang digunakan dalam penelitian : a) Kapas Alkohol 70\%, b) Darah Vena, c) natrium sitrat 3,8\%, d) $\mathrm{NaCl} 0,85 \%$, d) reagen control positif, e) sputum, f) pewarnna ziehl nelson.

Penelitian ini dilakukan untuk mengetahui hubungan antara kadar LED dengan kadar CRP, maka terlebih dahulu dilakukan Uji Normalitas dengan menggunakan uji Skewness yang bertujuan untuk mengetahui apakah data tersebut berdistribusi normal atau berdistribusi tidak normal. Jika data berdistribusi normal, hasil perhitung berada dalam rentang Zx maka dilakukan uji korelasi dengan metode Pearson's (r), dan jika data berdistribusi tidak normal (nilai $\mathrm{P}<0,01$ ) maka dilakukan uji korelasi dengan metode Spearmen $\left(r_{s}\right)$.

\section{Hasil Penelitian dan Pembahasan}

Pengumpulan data yang dilakukan dalam penelitian ini meliputi pengumpulan data skunder dan data primer dengan pemeriksaan LED dan CRP pasien Tuberkulosis (TBC). Hasil pemeriksaan dijabarkan pada tabel - tabel berikut :

Tabel 1. Distribusi penderita TBC berdasarkan hasil pemeriksaan kadar LED

\begin{tabular}{|c|c|c|c|c|c|c|c|}
\hline \multirow[t]{3}{*}{ No } & \multirow[t]{3}{*}{ Hasil pemeriksaan BTA } & \multicolumn{4}{|c|}{ Kadar LED } & \multicolumn{2}{|c|}{ Total } \\
\hline & & \multicolumn{2}{|c|}{ Normal } & \multicolumn{2}{|c|}{ Tidak normal } & \multirow[b]{2}{*}{$\mathbf{n}$} & \multirow[b]{2}{*}{$\%$} \\
\hline & & $\mathbf{n}$ & $\%$ & $\mathbf{n}$ & $\%$ & & \\
\hline 2. & $2+$ & $\mathbf{0}$ & $\mathbf{0}$ & $\mathbf{0}$ & $\mathbf{0}$ & $\mathbf{0}$ & $\mathbf{0}$ \\
\hline 3. & $3+$ & $\mathbf{0}$ & $\mathbf{0}$ & 1 & 9,1 & 1 & 9,1 \\
\hline 4. & Negatif & $\mathbf{0}$ & $\mathbf{0}$ & 7 & 63.6 & 7 & 63,6 \\
\hline
\end{tabular}


Penderita TBC dengan BTA negatif sebanyak 7 orang $(63,6 \%)$ dan responden dengan BTA positif sebanyak 4 orang $(36,4 \%)$ yang terdiri dari responden dengan BTA $1+$ sebanyak 3 orang $(27,3 \%)$, dan BTA $3+$ sebanyak 1 orang $(9,1 \%)$. Baik pada responden dengan BTA negatif dan BTA positif keduanya memiliki kadar LED tidak normal.

Tabel 2. Distribusi penderita TBC berdasarkan hasil pemeriksaan kadar CRP

\begin{tabular}{cccccccc}
\hline No & $\begin{array}{c}\text { Hasil BTA setelah } \\
\text { terapi OAT }\end{array}$ & \multicolumn{2}{c}{ Normal } & Tadar CRP & \multicolumn{2}{c}{ Total } \\
& & n & $\%$ & n & $\%$ & n & $\%$ \\
\hline 1. & $1+$ & 0 & 0 & 3 & 60 & 3 & 27,3 \\
2. & $2+$ & 0 & 0 & 0 & 0 & 0 & 0 \\
3. & $3+$ & 0 & 0 & 1 & 20 & 1 & 9,1 \\
4. & Negatif & 6 & 100 & 1 & 20 & 7 & $\mathbf{6 3 , 6}$ \\
\hline & Total & $\mathbf{6}$ & $\mathbf{0}$ & $\mathbf{5}$ & $\mathbf{1 0 0}$ & $\mathbf{1 1}$ & $\mathbf{1 0 0}$ \\
\hline
\end{tabular}

Semua penderita TBC dengan BTA positif yaitu sebanyak 4 orang mengalami peningkatan kadar CRP (tidak normal) yang terdiri dari responden BTA $1+$ sebanyak 3 orang (60\%) dan BTA 3+ sebanyak 1 orang $(20 \%)$, sedangkan responden dengan BTA negatif yang memiliki kadar CRP normal sebanyak 6 orang (100\%) dan 1 orang $(20 \%)$ memiliki kadar CRP tidak normal.

Tabel 3. Distribusi penderita TBC berdasarkan hasil pemeriksaan kadar LED dan kadar CRP

\begin{tabular}{|c|c|c|c|c|c|c|c|}
\hline \multirow[t]{3}{*}{ Hasil BTA } & \multirow[t]{3}{*}{ LED } & \multicolumn{4}{|c|}{ CRP } & \multicolumn{2}{|c|}{ Total } \\
\hline & & \multicolumn{2}{|c|}{ Normal } & \multicolumn{2}{|c|}{ Tidak normal } & \multirow[b]{2}{*}{$\mathbf{n}$} & \multirow[b]{2}{*}{$\%$} \\
\hline & & $\mathbf{N}$ & $\%$ & $\mathbf{n}$ & $\%$ & & \\
\hline \multirow[t]{2}{*}{ BTA Positif } & normal & $\mathbf{0}$ & $\mathbf{0}$ & $\mathbf{0}$ & $\mathbf{0}$ & $\mathbf{0}$ & $\mathbf{0}$ \\
\hline & Tidak normal & $\mathbf{0}$ & $\mathbf{0}$ & 4 & 80 & 4 & 36,4 \\
\hline \multirow[t]{2}{*}{ BTA negatif } & normal & $\mathbf{0}$ & $\mathbf{0}$ & $\mathbf{0}$ & $\mathbf{0}$ & $\mathbf{0}$ & $\mathbf{0}$ \\
\hline & Tidak normal & 6 & 100 & 1 & 20 & 7 & 63,6 \\
\hline \multicolumn{2}{|c|}{ Total } & 6 & 54,5 & 5 & 45,5 & 11 & 100 \\
\hline
\end{tabular}

Penderita TBC dengan hasil pemeriksaan BTA positif sebanyak 4 orang $(36,4 \%)$ sedangkan penderita TBC dengan hasil pemeriksaan BTA negatif sebanyak 7 orang (63,6\%). Dari tabel 4.7 tersebut telihat bahwa semua penderita TBC dengan hasil pemeriksaan BTA positif memiliki kadar LED dan CRP yang tidak normal. Penderita TBC yang hasil pemeriksaan BTA negatif memiliki kadar LED tidak normal namun memiliki kadar CRP normal sebanyak 6 orang (100\%) dan 1 orang (20\%) yang memiliki kadar LED dan kadar CRP tidak normal.

Tabel 4. Hasil Pemeriksaan Kadar LED dan Kadar CRP Pada Penderita TBC

\begin{tabular}{|c|c|c|c|}
\hline Hasil Pemeriksaan BTA & Kode & $\begin{array}{c}\text { Kadar LED } \\
\text { (mm/Jam) }\end{array}$ & $\begin{array}{c}\text { Kadar CRP } \\
(\mathrm{mg} / \mathrm{L})\end{array}$ \\
\hline \multirow[t]{4}{*}{ BTA Positif } & 1 & 110 & 48 \\
\hline & 2 & 103 & 24 \\
\hline & 3 & 89 & 24 \\
\hline & 4 & 103 & 48 \\
\hline \multicolumn{2}{|c|}{ Rata-rata } & 101,3 & 36 \\
\hline
\end{tabular}


BTA Negatif

\begin{tabular}{cccc}
5 & 28 & 6 \\
\hline 6 & 16 & 0 \\
\hline 7 & 21 & 0 \\
\hline 8 & 18 & 0 \\
\hline 9 & 23 & 0 \\
\hline 10 & 17 & 0 \\
\hline 11 & 21 & 0 \\
\hline & $\mathbf{2 0 , 6}$ & $\mathbf{0 , 9}$
\end{tabular}

\section{Rata-rata}

$\mathbf{0 , 9}$

Penderita TBC dengan hasil pemeriksaan BTA positif memiliki rata-rata kadar LED sangat tinggi yaitu sebesar 101,3 mm/jam, sedangkan rata-rata kadar CRP sebesar 36 mg/L. Pada penderita TBC dengan hasil pemeriksaan BTA negatif memiliki rata-rata kadar LED sebesar 20,6 mm/jam sedangkan rata-rata kadar CRP sebesar $0,9 \mathrm{mg} / \mathrm{L}$.

Tabel 5. Hubungan Antara Kadar LED dengan CRP pada Penderita TBC

\begin{tabular}{|l|l|l|l|}
\hline & & Kadar LED & Kadar CRP \\
\hline Kadar LED & Pearson & 1 & $.944^{* *}$ \\
\hline & Correlation sig. (1-tailed) N & 11 & 11 \\
\hline Kadar CRP & Pearson & $.944^{* *}$ & 1 \\
\hline & Correlation sig. (1-tailed) & .000 & \\
& $\mathrm{~N}$ & 11 & 11 \\
\hline
\end{tabular}

** Correlation is significant at the 0.01 level ( 1-tailed)

Tuberkulosis adalah suatu penyakit infeksi kronikyang disebabkan oleh bakteri berbentuk batang (basil) dengan nama Mycrobacterium tuberculosis. Mycrobacterium tuberculosis masuk ke dalam tubuh kemudian menyebabkan inflamasi, inflamasi terjadi invasi bakteri yang selanjutnya menginduksi sel hati untuk mensintesis protein fase akut sebagai proses pertahanan tubuh. Subjek penelitian ini adalah penderita TBC dalam terapi OAT (obat anti tuberkulosis).

Responden dengan BTA negatif sebanyak 7 orang $(63,6 \%)$ dan responden dengan BTA positif sebanyak 4 orang $(36,6 \%)$ yang terdiri dari responden dengan BTA $1+$ sebanyak 3 orang $(27,3 \%)$, dan BTA $3+$ sebanyak 1 orang $(9,1 \%)$. Baik pada responden dengan BTA negatif dan BTA positif keduanya memiliki kadar LED tidak normal.

Rata-rata kadar LED pada penderita TBC dengan hasil pemeriksaan BTA positif yaitu sebesar 101,6 mm/jam sedangkan rata-rata kadar LED pada penderita TBC dengan hasil pemeriksaan BTA negatif sebesar 20,6 mm/jam. Masih ditemukanya nilai LED tinggi pada penderita negatif tuberculosis disebabkan oleh masih adanya lesi aktif akibat adanya inflamasi oleh kuman TB yang awalnya sehingga menyebakan hasil LED sangat tinggi dan penurunan nilai LED tapi masih lebih dari normal menjunjukan adanya suatu perbaikan akan tetapi masih belum menunjukan nilai normal kemungkinan disebabkan lama waktu pegobatan yang digunakan dalam penelitian ini belum tuntas (Ningrum, 2017). Pemberian terapi OAT secara teratur dan berkesinambungan tanpa putus obat selama minimal 6 bulan dapat membunuh bakteri M. Tuberculosis, sehingga reaksi inflamasi pada tubuh akan berkurang. Dengan demikian, komponen sel-sel inflamasi di dalam plasma juga akan berkurang dan kembali normal sehingga angka tersebut akan menurun dan kembali normal pada pengukuran LED berikutnya(Hasan, 2010) . Menurut (Brajedenta \& Sumaerah, 2019) tetap tingginya kadar LED dapat 
disebabkan oleh seperti adanya infeksi maupun faktor-faktor lain yang menyebabkan tetap tingginya laju endap darah,. Selain itu hal tersebut dapat terjadi karena pemberian rifampisin yang digunakan sebagai OAT karena rifampicin merupakan hepatotoksik terutama jika pemakaiannya dikombinasikan dengan isoniazid yang juga toksik terhadap organ hati. Hal ini dapat menyebabkan tetap tingginya angka LED pada pasien tersebut (Brajedenta \& Sumaerah, 2019)

Hal ini menunjukkan bahwa pada penderita TBC, baik dengan kondisi ditemukan atau tidaknya bakteri BTA (BTA positif / BTA negatif) pada pemeriksaan sampel sputum dapat menyebabkan terjadinya peningkatan kadar LED pada penderita TBC. Hal ini dipertegas oleh pernyataan (Abul Abbas Andrew H. Lichtman Shiv Pilla, 2011)yang menyatakan bahwa terjadinya peningkatan kadar LED pada penderita tuberkulosis dikarenakan merupakan infeksi bakteri intraseluler yang pertama kali dihadapi oleh neutrofil kemudian bakteri ditangkap oleh makrofage dan Natural Killer sehingga menghasilkan sel T CD4 ${ }^{+}$dan $\mathrm{CD}^{+}$. Sel $\mathrm{T}$ ini kemudian menghasilkan IFN- $\gamma$ dan TNF. IFN- $\gamma$ dan TNF memiliki peran dalam mengaktivasi makrofag (Tahan et al., 2019).

Pengaktifan protein dapat terjadi peningkatan protein fase akut yang menyebabkan meningkatnya agregasi eritrosit membentuk reouleaux diiringi dengan terjadinya pengendapan reouleaux eritrosit sehingga didapatkan kadar laju endap darah tidak normal pada akhir fase pengendapan melambat. Kadar LED masih berada dalam kadar tidak normal pada seluruh responden dari hasil BTA negatif paska terapi bahkan hingga bulan ke enam setelah dilakukan terapi dapat disebabkan karena adanya pengaruh usia terjadi pada 1 responden diatas umur 60 tahun. Semakin tua usia seseorang maka akan semakin menurun fungsi organ - organ tubuhnya, sehingga imunitas pun juga menurun. Selanjutnya dapat dikarenakan pengaruh obat yang dikonsumsi dalam proses terapi memiliki efek samping yang berbeda - beda yang dapat merangsang peningkatan LED karena terjadi peradangan seperti gangguan pengliatan, insomnia, dan erupsi kulit. Begitupun dengan responden yang dinyatakan hasil BTA negatif setelah terapi tetapi kadar LED meningkatkan kemungkinan dikarenakan responden tersebut masih dalam proses penyembuhan TBC akibat bekas lesi sarang bakteri, hal ini dikarenakan walaupun BTA sudah negatif akan tetapi dapat meninggalkan sedikit bekas antara lain sarang ghon, garis fibrotic, maupun sarang pengkapuran dihilus, sehingga wajar kadar LED masih tidak normal karena masih adanya bekas lesi yang harus di sembuhkan oleh tubuh. (Ningrum, 2017)

Semua responden dengan BTA positif yaitu sebanyak 4 orang mengalami peningkatan kadar CRP (tidak normal) yang terdiri dari responden BTA $1+$ sebanyak 3 orang (60\%) dan BTA 3+ sebanyak 1 orang (20\%), sedangkan responden dengan BTA negatif yang memiliki kadar CRP normal sebanyak 6 orang (100\%) dan 1 orang $(20 \%)$ memiliki kadar CRP tidak normal. Berdasarkan tabel 4.8 pada penelitian ini terlihat bahwa penderita TBC dengan hasil pemeriksaan BTA positif memiliki rata-rata kadar CRP sebesar $36 \mathrm{mg} / \mathrm{L}$, sedangkan rata-rata kadar CRP pada penderita TBC dengan hasil pemeriksaan BTA negatif sebesar 0,9 mg/L. Hal ini menunjukkan bahwa pada penderita TBC yang masih ditemukan adanya bakteri BTA pada pemeriksaan sampel sputum (BTA positif) akan menyebabkan peningkatan kadar CRP pada penderita TBC. Demikian sebaliknya jika pada pemeriksaan sputum pada penderita TBC tidak ditemukan adanya bakteri BTA (BTA negatif) maka kadar CRP akan menurun (normal). C active Protein ( CRP) tipe protein khusus yang diproduksi hati ketika terjadi cedera akut, peradangan, infeksiselanjutnya CRP mengikat senyawa fosforil kolin pada 
lapisan luar bakteri yang masuk kedalam tubuh sehingga sintesa CRP dihati berlangsung sangat cepat setelah ada sedikit rangsangan, konsentrasi serum meningkat(Kosasih; E.N.dan A.S. Kosasih, 2008).Pada penderita TBC dalam terapi OAT bertujuan untuk menyembuhkan dan memusnakan BTA(Handojo indro, 2004) tentang protein menyatakan bahwa kadar CRP akan menurun tajam bila peradangan atau kerusakan jaringan mereda hingga mencapai nilai normal kembali.

Semua penderita TBC dengan hasil pemeriksaan BTA positif memiliki kadar LED dan CRP yang tidak normal. Penderita TBC yang hasil pemeriksaan BTA negatif memiliki kadar LED tidak normal namun memiliki kadar CRP normal sebanyak 6 orang (100\%) dan 1 orang (20\%) yang memiliki kadar LED dan kadar CRP tidak normal. Hal ini menunjukkan bahwa semua pada penderita TBC yang hasil pemeriksaan BTA positif, akan menyebabkan terjadinya peningkatan kadar LED dan kadar CRP. Namun jika penderita TBC yang hasil pemeriksaan BTA negatif akan menyebabkan terjadianya peningkatan pada kadar LED tapi belum tentu akan meningkatkan kadar CRP. Pernyataan di atas diperkuat oleh (Bray et al., 2016) yang menyatakan bahwa CRP memiliki sensitivitas yang tinggi dengan keberadaannya mendahului peningkatan LED selama inflamasi dan nekrosis. CRP mengikat langsung pada mikroorganisme sebagai opsonin untuk komplemen, mengaktivasi neutrofil dan menginhibisi agregasi trombosit. Semakin besar stimulusnya dalam tubuh, maka akan semakin tinggi dan lama kadar CRP bertahan, setelah stimulus dihilangkan nilai CRP akan turun dengan cepat dan segera kembali kekeadaan normalnya sedangkan LED dipengaruhi oleh beberapa protein plasma sehingga kadar LED meningkat secara lambat dari onset inflamasi dan tetap tinggi beberapa minggu setelah inflamasi teratasi.

\section{Kesimpulan}

Rata-rata nilai LED pada penderita tuberkulosis dengan BTA positif adalah sebesar 101,3 mm/jam dan kadar CRP sebesar 36 mg/L sedangkan rata-rata kadar LED pada penderita TBC dengan BTA negatif sebesar 20,8 mm/jam dan kadar CRP 0,9 mg/L. Hasil korelasi bahwa terdapat hubungan yang kuat antara kadar LED dengan kadar CRP pada penderita tuberkulosis.

\section{Daftar Pustaka}

Abul Abbas Andrew H. Lichtman Shiv Pilla. (2011). Cellular and Molecular Immunology (Elsevier S). Philadelphia.

Adriana Patricia Muñoz Zapata, L. C. C. (2011). No Title p. Phys. Rev. E, 24. Retrieved from http://ridum.umanizales.edu.co:8080/jspui/bitstream/6789/377/4/Muñoz_Zapata_Adriana_Patricia_Artí culo_2011.pdf

Alsagaff, H. (2009). Dasar-Dasar Ilmu Penyakit Paru. Surabaya: Airlangga University Press.

Brajedenta, G. S., \& Sumaerah. (2019). STUDI PADA PASIEN TUBERKULOSIS ANAK Therapeutic Effect of Anti Tuberculosis Drugs on Erythrocyte Sedimentation Rate : Study of Childhood Tuberculosis Penyakit tuberkulosis ( $T B$ ) paru masih merupakan suatu masalah kesehatan di Indonesia. Hingga saat ini. 5, 1-6. 
Bray, C., Bell, L. N., Liang, H., Haykal, R., Kaiksow, F., Mazza, J. J., \& Yale, S. H. (2016). Erythrocyte sedimentation rate and $\mathrm{C}$-reactive protein measurements and their relevance in clinical medicine. Wisconsin Medical Journal, 115(6), 317-321.

Handojo indro. (2004). Imunoasai Terapan pada Beberapa Penyakit Infeksi. Surabaya: Pusat Penerbitan dan Percetakan Unair (AUP).

Hasan, H. (2010). (2010). . Tuberkulosis Paru. Buku Ajar Ilmu Penyakit Paru FK Unair. Edisi Ke 2.

Kementerian Kesehatan Republik Indonesia. (2011). Pedoman Nasional Pengendalian TuberkulosisKeputusan Menteri Kesehatan Republik Indonesia Nomor 364. Jurnal ICT, (Pengendalian Tuberkulosis), 110.

Kosasih; E.N.dan A.S. Kosasih. (2008). Tafsiran Hasil Pemeriksaan Laboratorium Klinik (ke 2). Tanggerang.: Karisma Publishing Group.

Lauralee Sherwood. (2012). Fisiologi Manusia dari Sel ke Sistem (Edisi 6). Jakarta: EGC.

Mehta, V. (2008). At a Glance Hematologi (edisi kedu). Jakarta: Erlangga.

Ningrum, W. L. (2017). Profil Laju Endap Darah Pada Pasien Tuberkulosis Paru Kasus Baru di Rsu Kota Tangerang Selatan.

Depkes RI, (2005). Pharmaceutical care. 1-110.

Tahan, B., Bta, A., Pasien, P., Biologi, S., Teknik, F., Samudra, U., \& Unsam, K. (2019). Pemeriksaan Jumlah Leukosit, Laju Endap Darah Dan Tuberculosis Paru Di Rsud Langsa Evaluation Of Leukosit, Blood Rate And Bacterial Acid (Bta) In Patients Of Lung Tuberculosis Disease At Langsa HospitaL Infeksi adalah keadaan masuknya bakteri atau mik. 1(2), 6-15.

Warnasih, S., Yulia, W., Yohan, B., Artika, I. M., \& Sasmono, R. T. (2014). Induksi Ekspresi Gen Sitokin / Kemokin pada Sel Makrofag Manusia yang Dipapar Virus Dengue Isolat Indonesia. 1(3), 146-157. 